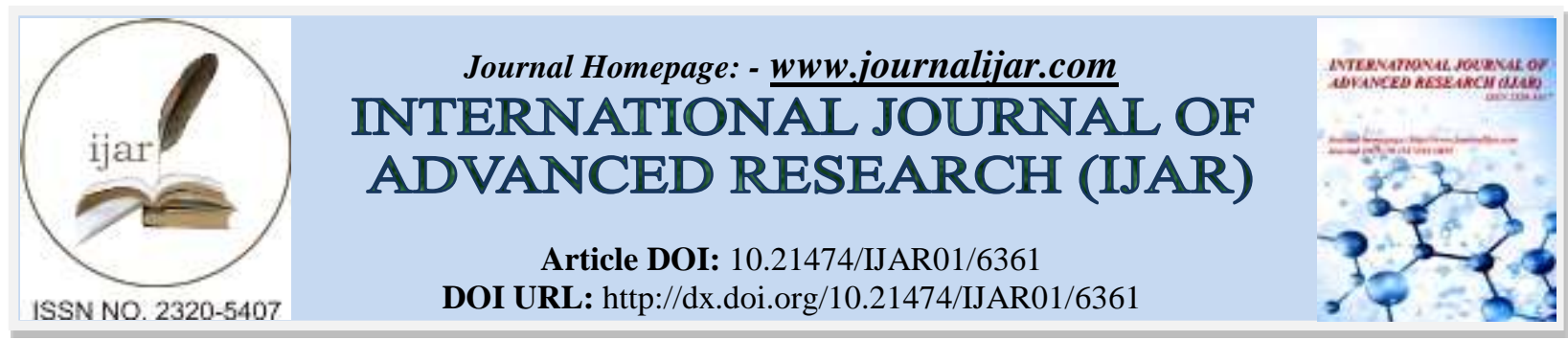

RESEARCH ARTICLE

\title{
HEALTH RISK ASSESSMENT OF SOME POTENTIALLY TOXIC ELEMENTS (PTES) IN RICE GROWN IN DEEKERNES SECTOR, DAKAHLEYA GOVERNORATE, EGYPT.
}

"H. M. Youssef, A. Kh. El-Fekky and M. M. El-Defrawy.

Chemistry Department, Faculty of Science, Mansoura University, P.O. Box 35516, Mansoura, Egypt.

\section{Manuscript Info}

Manuscript History

Received: 20 November 2017

Final Accepted: 22 December 2017

Published: January 2018

Key words:-

rice samples, PTEs, hazard index.

\begin{abstract}
Soil pollution with potentially toxic elements (PTEs) resulting from rapid industrial development has caused major concerns. Selected PTEs such as $(\mathrm{Cd}, \mathrm{Cu}, \mathrm{Pb}, \mathrm{Zn}, \mathrm{Cr}, \mathrm{Ni}$, and $\mathrm{Fe})$ and their accumulation in rice grown in the Deekernes sector irrigation area in mediates Dakahleya, Egypt were analyzed to evaluate the potential health risk to the local population. In this paper, five rice samples were collected from different areas namely. Daily intake rate and Target hazard quotient were used for the potential health risk assessment of local population through the intake of rice grown in the sewage-irrigated site. The results showed that continuous application of wastewater has led to accumulation of heavy metals in the soil, and $\mathrm{Cd}, \mathrm{Zn}, \mathrm{Cu}$ were the main pollutants. The risk assessment of PTEs through rice consumption suggests that the concentrations of $\mathrm{Cd}, \mathrm{Zn}, \mathrm{Ni}$ and $\mathrm{Cu}$ in some rice samples exceed their reference oral dose for adults and children. In general, hazard index values for adults and children were greater than 1 in S1, S3, S4, and S5. Potential health risks from exposure to heavy metals in self-planted rice need more attention.
\end{abstract}

Copy Right, IJAR, 2018,. All rights reserved.

\section{Introduction:-}

Food contamination by heavy metals has become a severe problem in recent years because of their potential accumulation in bio-systems through polluted water and soil sources [1]. Living organisms require variable amounts of essential heavy metals. Iron, Copper, and Zinc are required for biochemical processes. Excessive levels can be harmful to human health. Other heavy metals such as Cadmium, Chromium, and Lead are toxic metals and their accumulation over the time in the living organisms can cause serious effects [2]. Like many organisms, heavy metals cannot be detoxified by the humans' body mechanism [3]. As a substitute, they tend to accumulate in different tissues such as liver, muscles and bone and threaten the health of humans. Therefore, the heavy metals are among the most of the pollutants which have received attention in many countries and considered the most dangerous category of pollutants in the nutritional compounds. The growing human population has increased the need for food supply. Rice is good protein and energy source. Demand for this product has increased in market in past five decades. Worldwide, people obtain about $27 \%$ and $20 \%$ of their energy and protein from rice, respectively [4]. Some studies have indicated excessive amount of heavy metals, especially for cadmium, chromium, and lead in rice grains from different countries [5-7]. These investigations have shown that anthropogenic activities such as industrial production, mining and transportation release a high amount of heavy metals to the water and soil sources used in the rice cultivation. Rice cropped even from non-polluted areas may be contaminated because of fertilizers, pesticides and sewage that are used in farm, containing cadmium, lead and other heavy metals $[8,9]$. The objective 
of this study was to investigate and monitor amounts of copper, cadmium, lead, chromium, nickel and iron in domestic cultivated rice collected from five different areas. Hazard Quotient (HQ) and Hazard Index (HI) were used to assess non-carcinogenic health risks from individual metals and the combined health risk from seven metals, respectively. The results of our study may provide some insight into PTE accumulation in the agricultural ecosystem and serve as a basis for comparison to other regions both in Egypt and worldwide. Furthermore, the levels of heavy metals in the selected rice samples were compared to the allowable limits set by FAO/WHO [10].

\section{Materials and methods:-}

\subsection{Study area}

Our study area is located in Deekernes sector, Dakahleya governorate, Egypt. Five areas were selected for this study which are: Arab Weda manor with rice type of 104 (S1), Deyaba manor with rice type of 4.25 (S2), Kadayma manor with rice type of 4.25 (S3), Zohairy manor with rice type of 4.25 (S4), El-Bahr El-Kadeem manor with rice type of 4.25 (S5) and the irrigation source was Bahr El-dahab bank.

\subsection{Sampling}

5 samples (2 kg. each) collected in triplicate from Deekernes sector in 5 sites were washed with distilled water and air-dried to constant weight. The rice hulls were separated from the white rice grains using a mill. The white rice and rice hull samples passed through a 50 mesh $(<0.3 \mathrm{~mm})$ sieve, sealed in a plastic box and stored at room temperature until future analysis.

\subsection{Samples preparation and analysis}

Rice samples were ashed at $450^{\circ} \mathrm{C}$ under gradual increase $\left(<50^{\circ} \mathrm{C} / \mathrm{h}\right) .6 \mathrm{M} \mathrm{HCl}(1: 1)$ is added, and the solution was evaporated to dryness. The residue is dissolved in $0.1 \mathrm{M} \mathrm{HNO}_{3}$ [11]. The digested solution was analyzed for $\mathrm{Pb}, \mathrm{Cd}$, $\mathrm{Cr}, \mathrm{Ni}, \mathrm{Cu}, \mathrm{Fe}$ and $\mathrm{Zn}$ contents using GBC, Sensaa Series Atomic Absorption Spectrometry (computerized AAS) with air-acetylene flame under the optimum instrumental conditions. Each sample was analyzed three times.

\subsection{Human risk assessment of PTEs through rice consumption}

\subsubsection{Estimated daily intake (EDI)}

According to some reports $[13,14]$ the daily intake of PTEs depends on both the concentration of the element in food and the daily food consumption. Furthermore, human body weight can also influence tolerance of the pollutants [13]. The estimated daily intake $\left(\mu \mathrm{g} \mathrm{kg}^{-1} \mathrm{day}^{-1} \mathrm{Bw}\right)$ of PTEs via rice consumption proposed to be calculated as following [15]:

$\mathrm{EDI}=\mathrm{C} \times \mathrm{Con} \times \mathrm{EF} \times \mathrm{ED} / \mathrm{Bw} \times \mathrm{AT}$

where $\mathbf{C}\left(\mu \mathrm{g} \mathrm{g}^{-1}\right)$ is the concentration of PTEs in the contaminated rice, Con $\left(\mathrm{g} \mathrm{person}^{-1}\right.$ day $\left.^{-1}\right)$ is the daily average consumption of rice, Bw ( $\mathrm{kg} \mathrm{person}^{-1}$ ) represents body weight, EF is exposure frequency (365 days year ${ }^{-1}$ ), ED is exposure duration (70 years, equivalent to the average lifespan), and AT is average time (365 days year ${ }^{-1}$ number of exposure years, assuming 70 years in this study). The average daily rice intakes of adults and children were considered to be 389.2 and 198.4 g person $^{-1}$ day $^{-1}$, respectively [15], and average adult and child body weights were considered to be 55.9 and $32.7 \mathrm{~kg}$, respectively, as used in many previous studies [16-19].

\subsubsection{Potential health risk of individual PTEs: Target hazard quotient (THQ)}

According to standard EPA methods, the risk of non-carcinogenic effects is expressed as the ratio of the dose resulting from exposure to site media compared to a dose that is believed to be without risk of effects, even in sensitive individuals [15]. This ratio is referred to as the target hazard quotient (THQ). The THQ for the locals through consumption of contaminated rice can therefore be assessed based on the food chain and the reference oral dose $\left(R_{f} D\right)$ for each PTE. The applied $\mathrm{R}_{\mathrm{f}} \mathrm{D}$ for $\mathrm{Cr}, \mathrm{Cu}, \mathrm{Pb}, \mathrm{Zn}, \mathrm{Cd}, \mathrm{Ni}$ and Fe was 1500, 40, 3.5, 300, $1.0,20$ and 700 $\mu \mathrm{g} \mathrm{kg}^{-1}$ day $^{-1}$, respectively. Oral reference doses were obtained from the Integrated Risk Information System [20], with the exception of $\mathrm{Pb}$ for which we used the formula $\mathrm{R}_{\mathrm{f}} \mathrm{D}=\mathrm{PTWI} / 7$, where PTWI is the provisional tolerable weekly intake $\left(\mathrm{mg} \mathrm{kg}^{-1} \mathrm{day}^{-1}\right)$ by the Joint FAO/WHO Expert Committee on Food Additives (JECFA) [21, 22]. The THQ is determined as follows: $\mathbf{T H Q}=\mathbf{E D I} / \mathbf{R}_{\mathbf{f}} \mathbf{D}$

If the value of THQ is less than one it is assumed to be safe for risk of non-carcinogenic effects. If it exceeds one it is believed that there is a chance of non-carcinogenic effects, with an increasing probability as the value of THQ increases [15]. 


\subsubsection{Potential health risk of combined PTEs: Hazard index (HI)}

Some previous studies $[15,23]$ reported that exposure to two or more pollutants may result in additive and/or interactive effects. THQs can therefore be summed across constituents to generate a hazard index (HI) for a specific receptor/pathway (e.g. diet) combination. The $\mathrm{HI}$ is a measure of the potential risk of adverse health effects from a mixture of chemical constituents in rice.

The HI through daily average consumption of rice for a human being was calculated as follows: $\mathbf{H I}=\mathbf{\Sigma}$ THQ

\begin{tabular}{|c|c|c|c|c|c|c|c|c|c|c|c|c|c|c|c|}
\hline \multirow[b]{2}{*}{$\begin{array}{l}\text { Elem } \\
\text { ent }\end{array}$} & \multicolumn{3}{|l|}{ S 1 } & \multicolumn{3}{|l|}{ S2 } & \multicolumn{3}{|l|}{ S 3 } & \multicolumn{3}{|l|}{ S 4} & \multicolumn{3}{|l|}{ S 5} \\
\hline & $\begin{array}{l}\text { Mea } \\
\mathrm{n}\end{array}$ & SD & $\begin{array}{l}\mathrm{RS} \\
\mathrm{D} \\
\%\end{array}$ & Mean & SD & $\begin{array}{l}\text { RSD } \\
\%\end{array}$ & $\begin{array}{l}\mathrm{Me} \\
\text { an }\end{array}$ & SD & $\begin{array}{l}\mathrm{RS} \\
\mathrm{D} \\
\%\end{array}$ & $\begin{array}{l}\mathrm{Me} \\
\text { an }\end{array}$ & SD & $\begin{array}{l}\mathrm{RS} \\
\mathrm{D} \\
\%\end{array}$ & $\begin{array}{l}\mathrm{Me} \\
\text { an }\end{array}$ & SD & $\begin{array}{l}\mathrm{RS} \\
\mathrm{D} \\
\%\end{array}$ \\
\hline $\mathrm{Cd}$ & $\begin{array}{l}0.00 \\
5\end{array}$ & $\begin{array}{l}2.91 \times \\
10^{-4}\end{array}$ & 2.1 & 0 & 0 & 0 & 0 & 0 & 0 & $\begin{array}{l}0.0 \\
03\end{array}$ & $\begin{array}{l}0.03 \\
5\end{array}$ & $\begin{array}{l}72 . \\
9\end{array}$ & 0 & 0 & 0 \\
\hline $\mathrm{Cu}$ & $\begin{array}{l}0.07 \\
5\end{array}$ & $6 \times 10^{-}$ & 8.1 & 0.033 & 0.01 & 31 & 0 & 0 & 0 & $\begin{array}{l}0.1 \\
37\end{array}$ & $\begin{array}{l}0.07 \\
5\end{array}$ & $\begin{array}{l}54 . \\
7\end{array}$ & 0 & 0 & 0 \\
\hline $\mathrm{Fe}$ & $\begin{array}{l}0.03 \\
13\end{array}$ & $5 \times 10^{-}$ & 16 & 0.173 & $\begin{array}{l}7.8 \times 1 \\
0^{-3}\end{array}$ & 4.5 & $\begin{array}{l}0.1 \\
41\end{array}$ & $\begin{array}{l}6.1 \times \\
10^{-3}\end{array}$ & 4.3 & $\begin{array}{l}0.1 \\
57\end{array}$ & $\begin{array}{l}8.6 \times \\
10^{-3}\end{array}$ & 5.5 & $\begin{array}{l}0.1 \\
53\end{array}$ & 0.02 & 13 \\
\hline $\mathrm{Pb}$ & 0 & 0 & 0 & 0 & 0 & 0 & 0 & 0 & 0 & 0 & 0 & 0 & 0 & 0 & 0 \\
\hline $\mathrm{Ni}$ & 0 & 0 & 0 & $\begin{array}{l}6.33 x \\
10^{-3}\end{array}$ & $\begin{array}{l}2.33 x \\
10^{-3}\end{array}$ & $\int_{-4} 1 \times 10$ & $\begin{array}{l}0.0 \\
67\end{array}$ & $\begin{array}{l}0.02 \\
4\end{array}$ & $\begin{array}{l}36 . \\
68\end{array}$ & $\begin{array}{l}0.0 \\
2\end{array}$ & $\begin{array}{l}0.02 \\
1\end{array}$ & $\begin{array}{l}10 . \\
5\end{array}$ & $\begin{array}{l}0.0 \\
13\end{array}$ & $\begin{array}{l}5.78 x \\
10^{-3}\end{array}$ & $\begin{array}{l}44 \\
5\end{array}$ \\
\hline $\mathrm{Zn}$ & $\begin{array}{l}0.03 \\
53\end{array}$ & $\begin{array}{l}7.2 \times 1 \\
0^{-3}\end{array}$ & $\begin{array}{l}20 . \\
45\end{array}$ & $\begin{array}{l}2.33 x \\
10^{-3}\end{array}$ & $\begin{array}{l}1.66 x \\
10^{-3}\end{array}$ & $\begin{array}{l}2.6 x \\
10^{-5}\end{array}$ & 0 & 0 & 0 & $\begin{array}{l}0.0 \\
58\end{array}$ & $\begin{array}{l}7 \times 10 \\
-4\end{array}$ & 1.2 & $\begin{array}{l}0.1 \\
43\end{array}$ & 1.22 & $\begin{array}{l}0.8 \\
5\end{array}$ \\
\hline $\mathrm{Cr}$ & 0 & 0 & 0 & 0 & 0 & 0 & 0 & 0 & 0 & 0 & 0 & 0 & 0 & 0 & 0 \\
\hline
\end{tabular}

2.4.4. Statistical analysis

The means, standard deviations (SD) and relative standard deviation percentage (RSD \%) were calculated using Microsoft Office Excel.

\section{Results and discussion:-}

\subsection{Heavy metal levels in rice samples}

The mean, standard deviations (SD) and relative standard deviation percentage (RSD \%) of heavy metals in investigated rice samples are presented in Table 1:

Table 1: Heavy metal levels in investigated rice samples:

\subsection{Daily PTE intakes via rice consumption and the risk to human health}

\subsubsection{Dietary PTE intake}

Although there are many pathways of human exposure to PTEs, rice consumption has been identified as one of the major pathways. Therefore, as rice consumption rises in Deekernes sector, human exposure to PTE contamination increases. Table shows the dietary intake of PTEs through rice consumption for adults and children in Deekernes sector on the assumption that the local population consumes mostly local rice. The mean dietary intakes of $\mathrm{Cd}, \mathrm{Cu}$, $\mathrm{Fe}, \mathrm{Pb}, \mathrm{Ni}, \mathrm{Zn}, \mathrm{Cr}$ through rice are estimated to be $2.0,26.7,1.2,132.8,0.1,0.1$, and $1.4 \mathrm{mg} \mathrm{kg}^{-1} \mathrm{day}^{-1}$ for adults, and $1.8,23.3,1.0,115.7,0.1,0.1$, and $1.2 \mathrm{mg} \mathrm{kg}^{-1}$ day $^{-1}$ for children. The mean estimated dietary intakes (MEDIs) of PTEs for adults are higher than those for children and this is in agreement with a previous study [15].

\subsubsection{Potential health risks}

In the present study, hazard index and carcinogenic risk approaches were used to evaluate the health risks of heavy metal exposure to rice. The non-cancer risk (HQ and HI) and cancer risks for adults and children are shown in Table $2(\mathrm{a}, \mathrm{b}, \mathrm{c}, \mathrm{d}$ and $\mathrm{e})$

\subsubsection{Potential health risk of individual PTEs (THQs)}

The THQs of individual PTEs through rice consumption for the residents (adults and children) in samples are listed in Table For adults, the THQ of PTEs from rice consumption is in decreasing order Cd $>$ $\mathrm{Zn}>\mathrm{Cu}>\mathbf{N i}>\mathrm{Fe}$ 
The THQ of PTEs for children is similar to that for adults. Our results suggest that Cd ingestion has the highest potential health risk of adverse effects for adults and children and Fe ingestion has the minimum risk for adults and children.

\subsubsection{Potential health risk of combined PTEs (HI)}

The hazard index (HI) for a specific receptor/pathway combination can be calculated [15]. The HI values through consumption of rice for adults and children in samples listed in table

This indicates that adults and children may experience adverse health effects. The HI value for adults through rice consumption is slightly higher than that for children, suggesting that the risk of non-carcinogenic effects for adults is slightly higher than that for children. $\mathrm{Cd}$ is the key component contributing to the potential health risk of noncarcinogenic effects for adults and children, with $\mathrm{Zn}, \mathrm{Cu}$ and $\mathrm{Ni}$ being secondary and $\mathrm{Fe}$ the least important.

Table 2:- Estimated daily intake by human beings and potential health risk of PTEs due to rice consumption:

\begin{tabular}{|c|c|c|c|c|c|}
\hline \multicolumn{6}{|c|}{ a. Sample 1 (S1) } \\
\hline Individuals & Element & $\mathbf{R}_{\mathrm{f}} \mathbf{D}$ & EDI & THQ & HI \\
\hline \multirow[t]{7}{*}{ Adult } & $\mathrm{Cd}$ & 1 & 2.43 & 2.43 & \multirow{7}{*}{3.42} \\
\hline & $\mathrm{Cu}$ & 40 & 36.55 & 0.913 & \\
\hline & $\mathrm{Fe}$ & 700 & 15.25 & 0.0217 & \\
\hline & $\mathrm{Pb}$ & 4 & 0 & 0 & \\
\hline & $\mathrm{Ni}$ & 20 & 0 & 0 & \\
\hline & $\mathrm{Zn}$ & 14 & 17.20 & 0.057 & \\
\hline & $\mathrm{Cr}$ & 1500 & 0 & 0 & \\
\hline \multirow[t]{7}{*}{ Children } & $\mathrm{Cd}$ & 1 & 2.1 & 2.1 & \multirow[t]{7}{*}{2.96} \\
\hline & $\mathrm{Cu}$ & 40 & 31.82 & 0.7955 & \\
\hline & $\mathrm{Fe}$ & 700 & 13.28 & 0.0189 & \\
\hline & $\mathrm{Pb}$ & 4 & 0 & 0 & \\
\hline & $\mathrm{Ni}$ & 200 & 0 & 0 & \\
\hline & $\mathrm{Zn}$ & 14 & 14.97 & 0.0499 & \\
\hline & $\mathrm{Cr}$ & 1500 & 0 & 0 & \\
\hline
\end{tabular}

b. Sample 2 (S2)

\begin{tabular}{|c|c|c|c|c|c|}
\hline Individuals & Element & $\mathbf{R}_{\mathbf{f}} \mathbf{D}$ & EDI & THQ & HI \\
\hline \multirow[t]{7}{*}{ Adult } & $\mathrm{Cd}$ & 1 & 0 & 0 & \multirow{7}{*}{0.6792} \\
\hline & $\mathrm{Cu}$ & 40 & 16.22 & 0.4055 & \\
\hline & $\mathrm{Fe}$ & 700 & 84.31 & 0.126 & \\
\hline & $\mathrm{Pb}$ & 4 & 0 & 0 & \\
\hline & $\mathrm{Ni}$ & 20 & 1.135 & 0.0037 & \\
\hline & $\mathrm{Zn}$ & 14 & 3 & 0.19 & \\
\hline & $\mathrm{Cr}$ & 1500 & 0 & 0 & \\
\hline \multirow[t]{7}{*}{ Children } & $\mathrm{Cd}$ & 1 & 0 & 0 & \multirow[t]{7}{*}{0.5937} \\
\hline & $\mathrm{Cu}$ & 40 & 14.1 & 0.3525 & \\
\hline & $\mathrm{Fe}$ & 700 & 73.4 & 0.104 & \\
\hline & $\mathrm{Pb}$ & 4 & 0 & 0 & \\
\hline & $\mathrm{Ni}$ & 20 & 0.988 & 0.00329 & \\
\hline & $\mathrm{Zn}$ & 14 & 2.68 & 0.134 & \\
\hline & $\mathrm{Cr}$ & 1500 & 0 & 0 & \\
\hline
\end{tabular}

c. Sample 3 (S3)

\begin{tabular}{|l|l|l|l|l|l|}
\hline Individuals & Element & $\mathbf{R}_{\mathbf{f}} \mathbf{D}$ & EDI & THQ & HI \\
\hline \multirow{5}{*}{ Adult } & $\mathrm{Cd}$ & 1 & 0 & 0 & \\
\cline { 2 - 5 } & $\mathrm{Cu}$ & 40 & 0 & 0 & 1.728 \\
\cline { 2 - 6 } & $\mathrm{Fe}$ & 700 & 68.71 & 0.098 & \\
\cline { 2 - 6 } & $\mathrm{Pb}$ & 4 & 0 & 0 & \\
\hline
\end{tabular}




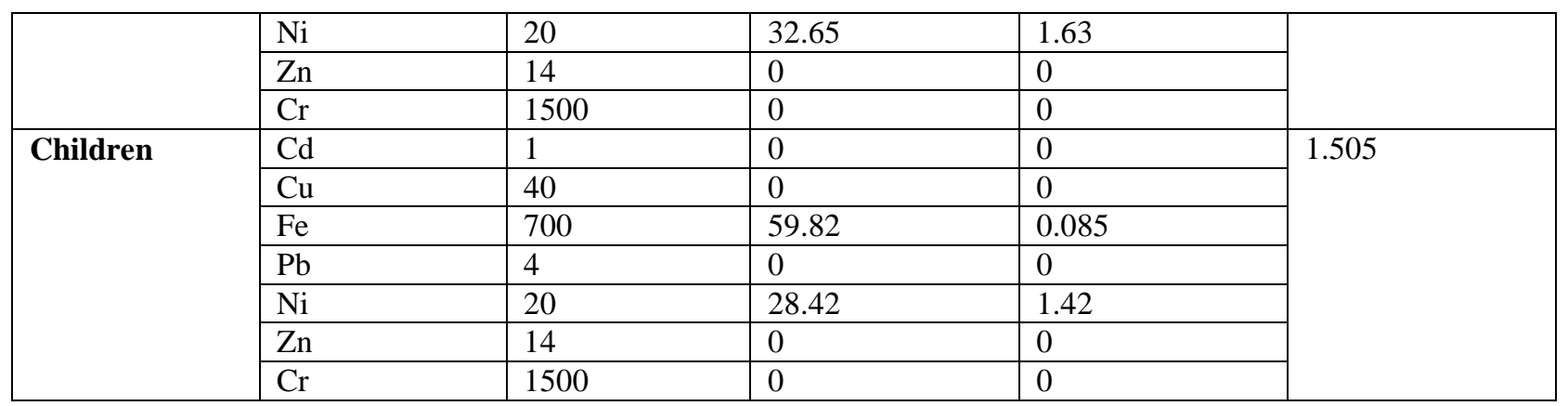

d. Sample 4 (S4)

\begin{tabular}{|c|c|c|c|c|c|}
\hline Individuals & Element & $\mathbf{R}_{\mathbf{f}} \mathbf{D}$ & EDI & THQ & HI \\
\hline \multirow{7}{*}{ Adult } & $\mathrm{Cd}$ & 1 & 1.46 & 1.46 & \multirow{7}{*}{3.8195} \\
\hline & $\mathrm{Cu}$ & 40 & 66.76 & 1.669 & \\
\hline & $\mathrm{Fe}$ & 700 & 76.51 & 0.1093 & \\
\hline & $\mathrm{Pb}$ & 4 & 0 & 0 & \\
\hline & $\mathrm{Ni}$ & 20 & 9.74 & 0.487 & \\
\hline & $\mathrm{Zn}$ & 14 & 28.26 & 0.0942 & \\
\hline & $\mathrm{Cr}$ & 1500 & 0 & 0 & \\
\hline \multirow{7}{*}{ Children } & $\mathrm{Cd}$ & 1 & 1.27 & 1.27 & \multirow{7}{*}{1.91} \\
\hline & $\mathrm{Cu}$ & 40 & 58.12 & 1.45 & \\
\hline & $\mathrm{Fe}$ & 700 & 66.61 & 0.095 & \\
\hline & $\mathrm{Pb}$ & 4 & 0 & 0 & \\
\hline & $\mathrm{Ni}$ & 20 & 8.485 & 0.424 & \\
\hline & $\mathrm{Zn}$ & 14 & 24.60 & 0.082 & \\
\hline & $\mathrm{Cr}$ & 1500 & 0 & 0 & \\
\hline
\end{tabular}

e. Sample 5 (S5)

\begin{tabular}{|c|c|c|c|c|c|}
\hline Individuals & Element & $\mathbf{R}_{\mathbf{f}} \mathbf{D}$ & EDI & THQ & HI \\
\hline \multirow{7}{*}{ Adult } & $\mathrm{Cd}$ & 1 & 0 & 0 & \multirow{7}{*}{5.392} \\
\hline & $\mathrm{Cu}$ & 40 & 0 & 0 & \\
\hline & $\mathrm{Fe}$ & 700 & 74.96 & 0.106 & \\
\hline & $\mathrm{Pb}$ & 4 & 0 & 0 & \\
\hline & $\mathrm{Ni}$ & 20 & 6.33 & 0.316 & \\
\hline & $\mathrm{Zn}$ & 14 & 69.69 & 4.97 & \\
\hline & $\mathrm{Cr}$ & 1500 & 0 & 0 & \\
\hline \multirow[t]{7}{*}{ Children } & $\mathrm{Cd}$ & 1 & 0 & 0 & \multirow{7}{*}{4.7} \\
\hline & $\mathrm{Cu}$ & 40 & 0 & 0 & \\
\hline & $\mathrm{Fe}$ & 700 & 64.91 & 0.092 & \\
\hline & $\mathrm{Pb}$ & 4 & 0 & 0 & \\
\hline & $\mathrm{Ni}$ & 20 & 5.51 & 0.275 & \\
\hline & $\mathrm{Zn}$ & 14 & 60.67 & 4.3 & \\
\hline & $\mathrm{Cr}$ & 1500 & 0 & 0 & \\
\hline
\end{tabular}

\section{Conclusion:-}

The soil in the Deekernes sector, Dakahleya governorate, Egypt are primarily contaminated with $\mathrm{Cd}$ while $\mathrm{Zn}, \mathrm{Cu}$ and Ni being secondary and Fe the least important.

The estimation of dietary intake of these PTEs by local inhabitants shows that the MEDIs for adults and children are all below their $\mathrm{R}_{\mathrm{f}} \mathrm{D}$ but in some rice samples $\mathrm{Cd}(\mathrm{S} 1, \mathrm{~S} 4), \mathrm{Cu}(\mathrm{S} 4), \mathrm{Ni}(\mathrm{S} 3)$ and $\mathrm{Zn}$ (S5) for adults and children are higher their $\mathrm{R}_{\mathrm{f}} \mathrm{D}$ also the THQ values of individual elements was greater than 1 through rice consumption. The HI values through rice consumption for adults and children indicating that both adults and children may experience some adverse health effects. Cadmium is the key component contributing to the potential health risk of non- 
carcinogenic effects for adults and children. Furthermore, considerable attention should also be paid to the potential health risks of PTEs through other exposure pathways.

In this study, locally produced rice is the main staple foodstuff and it makes the dominant contribution to the metal intake of residents. To avoid a large accumulation of toxic metals in the human body, local people are not recommended to grow rice crops in land irrigated with metal-contaminated water or to consume large quantities of these contaminated rice grains. Moreover, contaminated soils can endanger human health through oral intake.

\section{References:-}

1. Lokeshwari H., \& Chandrappa G. T., Impact of heavy metal contamination of Bellandur Lake on soil and cultivated vegetation, Current Science, 91(5) ( 2006) 622-627.

2. Onsanit S., Ke C., Wang X., Wang K.-J., \& Wang W.-X., Trace elements in two marine fish cultured in fish cages in Fujian province, China, Environmental Pollution, 158(5) (2010) 1334-1342.

3. Castro-Gonzlez M. I., \& Méndez-Armenta M., Heavy metals: Implications associated to fish consumption, Environmental Toxicology and Pharmacology, 26(3) (2008) 263-271.

4. Juliano, B. O., Rice in human nutrition, FAO Food and Nutrition Series, No. 26. Food and Agriculture Organization of the United Nations, Rome, Italy, (1993) 162

5. Batista, B. L., Determination of essential (Ca, Fe, I, K, Mo) and toxic elements $(\mathrm{Hg}, \mathrm{Pb})$ in Brazilian rice grains and estimation of reference daily intake, Food and Nutrition Sciences, 3 (2012) 129-134.

6. Jung, M. C., Yun, S. T., Lee, J. S., \& Lee, J. U., Baseline study on essential and trace elements in polished rice from South Korea. Environmental Geochemistry and Health, 27(5-6) (2005) 455-464.

7. Zhang, Z. W., Watanabe, T., Shimbo, S., Higashikawa, K., \& Ikeda, M., Lead and cadmium contents in cereals and pulses in north-eastern China, Science of the Total Environment, 220 (2-3) (1998) 137-145.

8. Jahed Khaniki, G., \& Zazoli, M., Cadmium and lead contents in rice (oryza sativa) in the north of iran. International Journal of Agriculture \& Biology, 7(6) (2005) 1026-1029.

9. Nriagu, J. O., \& Pacyna, J. M., Quantitative assessment of worldwide contamination of air, water and soils by trace metals. Nature, 333 (1988) 134-139.

10. In M. Sheffer (Ed.), Principles and methods for the risk assessment of chemicals in food. Wissenchaftliche VerlagsgesellschaftmbH, Germany, FAO/WHO, (2009) 95.

11. Jorhem, L., Determination of metals in foods by atomic absorption spectrometry after dry ashing: NMKL collaborative study. Journal of AOAC International, 83(5) (2000) 1204-1211.

12. Zhong, J.M., Yu, M., Liu, L.Q., Chen, Y.P., Hu, R.Y., Gong, W.W., Study on the dietary nutrition intake level in Zhejiang Province, Disease Surveillance, 21 (2006) 670-672.

13. Fu, J.J., Zhou, Q.F., Liu, J.M., Liu, W., Wang, T., Zhang, Q.H., Jiang, G.B., High levels of heavy metals in rice (Oryza sativa L.) from a typical E-waste recycling area in southeast China and its potential risk to human health, Chemosphere, 71 (2008) 1269-1275

14. Liu, H.Y., Probst, A., Liao, B.H., Metal contamination of soils and crops affected by the Chenzhou lead/zinc mine spill, Science of the Total Environment, 339 (2005) 153-166.

15. Zheng, N., Wang, Q.C., Zhang, X.W., Zheng, D.M., Zhang, Z.S., Zhang, S.Q., Population health risk due to dietary intake of heavy metals in the industrial area of Huludao City, China, Science of the Total Environment, 387 (2007a) 96-104.

16. Ge, K.Y., The Status of Nutrient and Meal of Chinese in the 1990s, Beijing People's Hygiene Press, Beijing, (1992) 415-434.

17. Khan, S., Cao, Q., Zheng, Y.M., Huang, Y.Z., Zhu, Y.G., Health risks of heavy metals in contaminated soil and food crops irrigated with wastewater in Beijing, China, Environmental Pollution, 152, (2008) 686-692.

18. Wang, X.L., Sato, T., Xing, B.S., Tao, S., Health risks of heavy metals to the general public in Tianjin, China via consumption of vegetables and fish, Science of the Total Environment, 350 (2005) 28-37.

19. Zheng, N., Wang, Q.C., Zheng, D.M., Health risk of $\mathrm{Hg}, \mathrm{Pb}, \mathrm{Cd}, \mathrm{Zn}$, and $\mathrm{Cu}$ to the inhabitants around Huludao Zinc Plant in China via consumption of vegetables, Science of the Total Environment 383, (2007b) 81-89.

20. US-EPA, IRIS. United States, Environmental Protection Agency, Integrated Risk Information System, accessed January 2008.

21. Food Consumption and Exposure Assessment of Chemicals, Report of FAO/WHO Consultation. WHO, Geneva, (1997) $17-25$.

22. UNEP/FAO/WHO, Assessment of Dietary Intake of Chemical Contaminants, WHO/HPP/FOS/92.6,UNEP/GEMS/92.F2.United Nations Environmental Program, Nairobi, 1992.

23. Harrison, R.M., Chirgawi, M.B., The assessment of air and soil as contributors of some trace metals to vegetable plants III - experiment with field-grown plants. Science of the Total Environment 83, (1989) 47-6003. 